\title{
Higher Excretion of Urinary Bound Amino Acids in Infants: Probably Related to Protein-Anabolic Effect of Growth Hormone
}

\author{
Tsuneo Arakawa, Takashi Saito, Akibumi Minagawa, \\ Ryuji Shioji, Mayumi Kobayashi,* Hideo Chikaoka $\dagger$ \\ and Noriko Katsushima + \\ Departments of Pediatrics and Internal Medicine, Tohoku \\ Teishin Hospital (NTT), Sendai 983, *Iwaki Kyoritsu Hospital, \\ Iwaki 973, †Yamagata Prefectural Hospital, Yamagata 990 \\ and $\ddagger$ Yamagata City Hospital, Yamagata 990
}

\begin{abstract}
Arakawa, Ts., Saito, T., Minagawa, A., Shioji, R., Kobayashi, M., Chikaoka, H. and Katsushima, N. Higher Excretion of Urinary Bound Amino Acids in Infants: Probably Related to Protein-Anabolic Effect of Growth Hormone. Tohoku J. exp. Med., 1982, 137 (1), I-10-Concentrations of bound amino acids in urine were found to be markedly higher in infants than in children over 4 years of age. And it was also found that bound amino acid levels in plasma were increased in infants and young children than in adults. Urinary excretion of bound amino acids was increased in a hypopituitary dwarf after one day of intramuscular injection of human growth hormone. A possibility was advanced that an increased excretion of bound amino acids of the overflow type observed in infants was due to active protein biosynthesis stimulated by growth hormone of which plasma levels have been reported to be high in infancy. bound aminoaciduria; growth hormone
\end{abstract}

Concentrations of bound amino acids in urine and plasma were examined on patients of various age groups. It was found that there was an increased bound aminoaciduria in infants and it was of the overflow type. In a hypopituitary dwarf, urinary excretion of bound amino acids was increased after one day of intramuscular injection of growth hormone. A possibility was advanced that an increased excretion of bound amino acids of the overflow type in infants was due to active protein biosynthesis stimulated by growth hormone of which plasma levels had been reported to be high in infancy.

\section{Methods and Materials}

Urine specimens were taken from 54 males under 11 years of age who visited Pediatrics Clinic of Tohoku Teishin Hospital and Iwaki Kyoritsu Hospital with complaints of minor illness. From some of patients admitted to these hospitals, heparinized plasma specimens were obtained on fasting in the morning.

A patient, S.T. was a 7-year-old boy who was diagnosed as hypopituitary dwarfism

Received for publication, August 10, 1981. 
on the basis of poor response of growth hormone secretion after arginine and insulin stimulation, and has been treated with human growth hormone (intramuscular injections of 2 i.u. of Corpormon twice a week) for past 10 months at Yamagata Prefectural Hospital.

Amino acid estimation was carried out using an automatic amino acid analyzer (Hitachi, Tokyo).

Before the amino acid assay, urine was deproteinized by adding $0.5 \mathrm{ml}$ of $40 \%$ sulfosalicylic acid to $5.0 \mathrm{ml}$ of urine, then filtered through the Toyo filter paper No. 5C, and creatinine content was estimated by the Jaffe reaction (Bonsness and Taussky 1945), then being adjusted to $20-30 \mathrm{mg} / 100 \mathrm{ml}$ and used for free amino acid assay.

The blood plasma was deproteinized by adding the plasma to an equal amount of $4 \%$ sulfosalicylic acid and centrifuged, and the supernatant was subjected to the free amino acid assay.

Concentrations of bound amino acids (Skarzynski and Sarnecka-Keller 1962) in urine and plasma were calculated from the difference between amino acid concentrations obtained before and after acid hydrolysis.

The acid hydrolysis was performed in sealed vacuum tubes containing $0.5 \mathrm{ml}$ of urine or plasma specimens which were prepared for the free amino acid assay, and $0.5 \mathrm{ml}$ of concentrated hydrochloric acid in a thermostatic oven at $110^{\circ} \mathrm{C}$ for $18 \mathrm{hr}$. The hydrolysates were then adjusted to $\mathrm{pH}$ 1.6-2.0 by adding $6 \mathrm{~N}$ sodium hydroxide solution, and then filtered. The clear filtrate was subjected to the amino acid assay.

\section{Results and Discussion}

Urinary concentrations of amino acid were expressed as $\mu$ moles per $\mathrm{mg}$ of creatinine. It was found that glycine, alanine, valine, cystine, methionine, isoleucine, leucine, phenylalanine, lysine, histidine, and arginine were found higher in infants than in children over 3 years of age, and that this tendency was more exaggerated in the case of bound amino acids than in that of free amino acids (Table 1, Figs. 1-6).

Bound amino acid concentrations in plasma obtained on fasting in the morning were found to be higher in infants and young children than in adults and seniles (Table 2, Figs. 7, 8). Since it was reported that bound amino acids in plasma
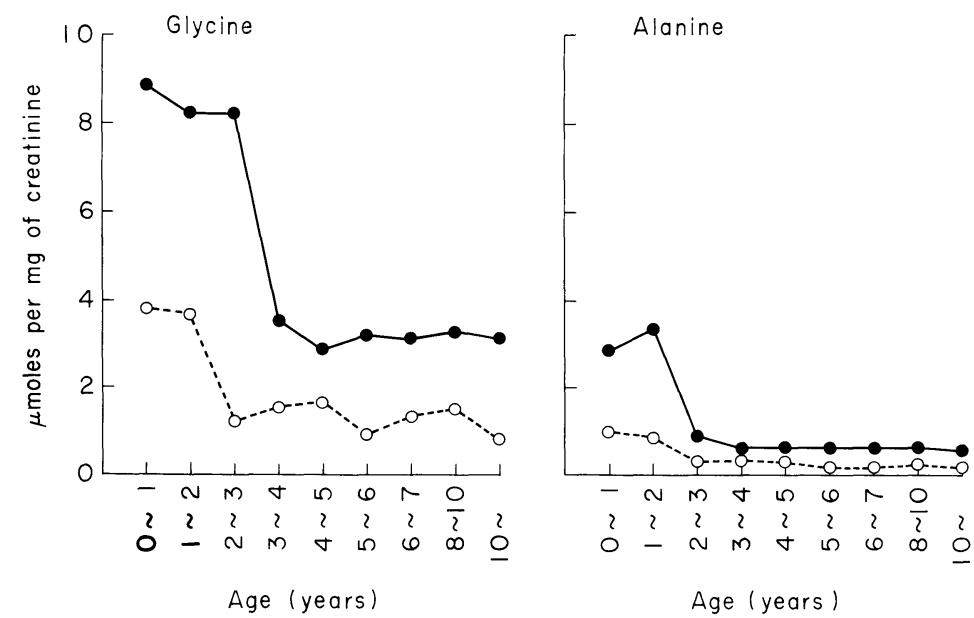

Fig. 1. Glycine and alanine in urine of male infants and children. acids; $0 \cdots 0$, free amino acids. 

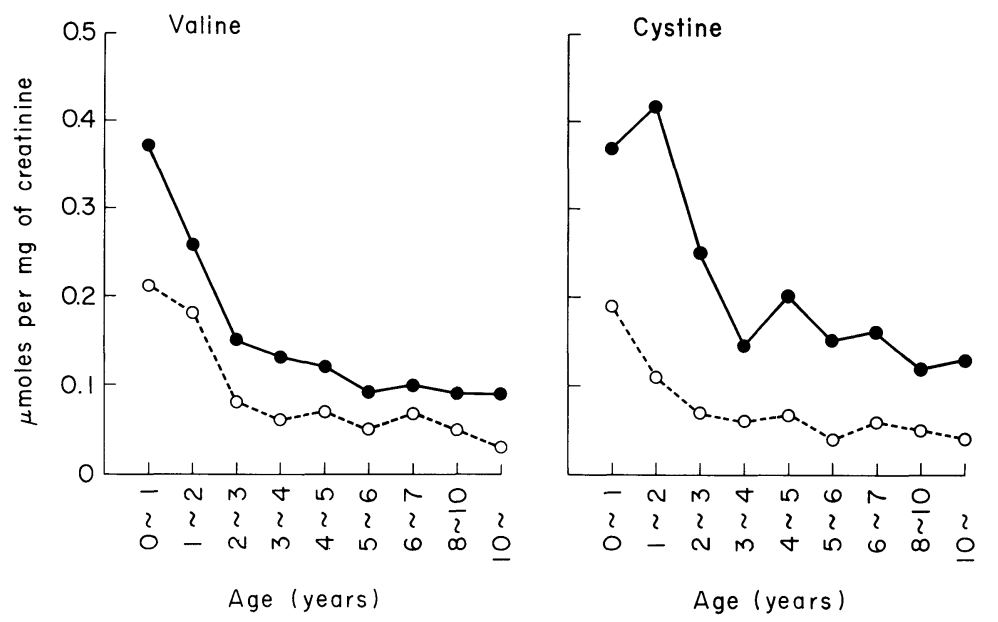

Fig. 2. Valine and cystine in urine of male infants and children (for symbols, see Fig. 1).
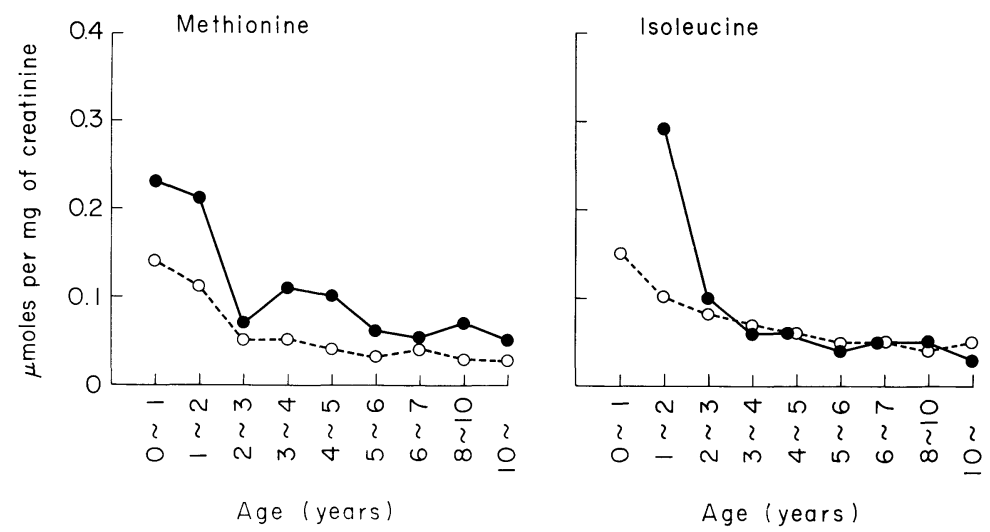

Fig. 3. Methionine and isoleucine in urine of male infants and children (for symbols, see Fig. 1).

were rapidly and almost completely cleared into urine (Silber and Porter 1949), it might be said that the increased bound aminoaciduria observed in infants and young children was of the overflow type.

In a hypopituitary dwarf who had been treated with human growth hormone (intramuscular injections of $2 \mathrm{i} . \mathrm{u}$. of Corpormon ${ }^{\circledR}$, twice a week) for past 10 months, it was found that there was an increase in concentrations of bound amino acids in plasma and urine (glycine, valine, cystine, methionine, isoleucine, leucine, phenylalanine, lysine, histidine, and arginine) as compared with those of control children (Table 3, Fig. 9). The urine and plasma samples used for these analysis were those obtained on 7 days after the intramuscular injection of 2 i.u. of Corpormon ${ }^{\circledR}$. In the same patient (S.T.) it was also found that urinary excretion of bound amino acids (valine, cystine, methionine, leucine, phenylalanine, 
Ts. Arakawa et al.

lysine, histidine, and proline) was increased after one day of the intramuscular injection of 2 i.u. of Corpormon ${ }^{\circledR}$ as compared with that before the injection (Table 4).

With respect to growth hormone and its relation to amino acids and protein metabolism, Stahnke et al. (1977) described as follows: An increase in protein biosynthesis in cells known to occur in response to human growth hormone is not only due to enhanced amino acid influx. Above all human growth hormone directly exerts its protein anabolic action by stimulating ribosomal activity and

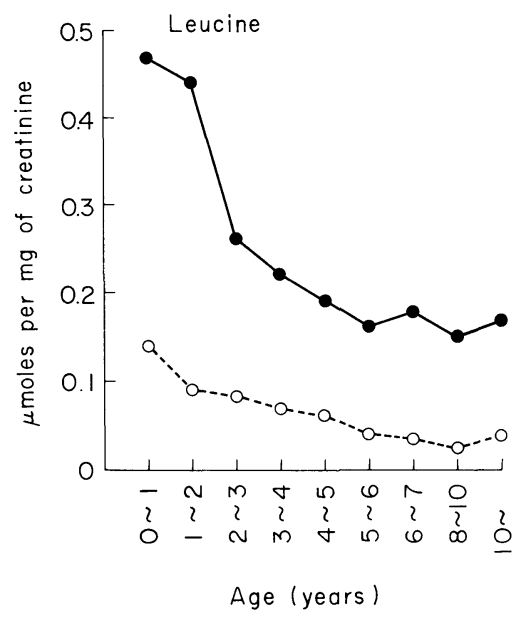

Fig. 4. Leucine in urine of male infants and children (for symbols, see Fig. 1).
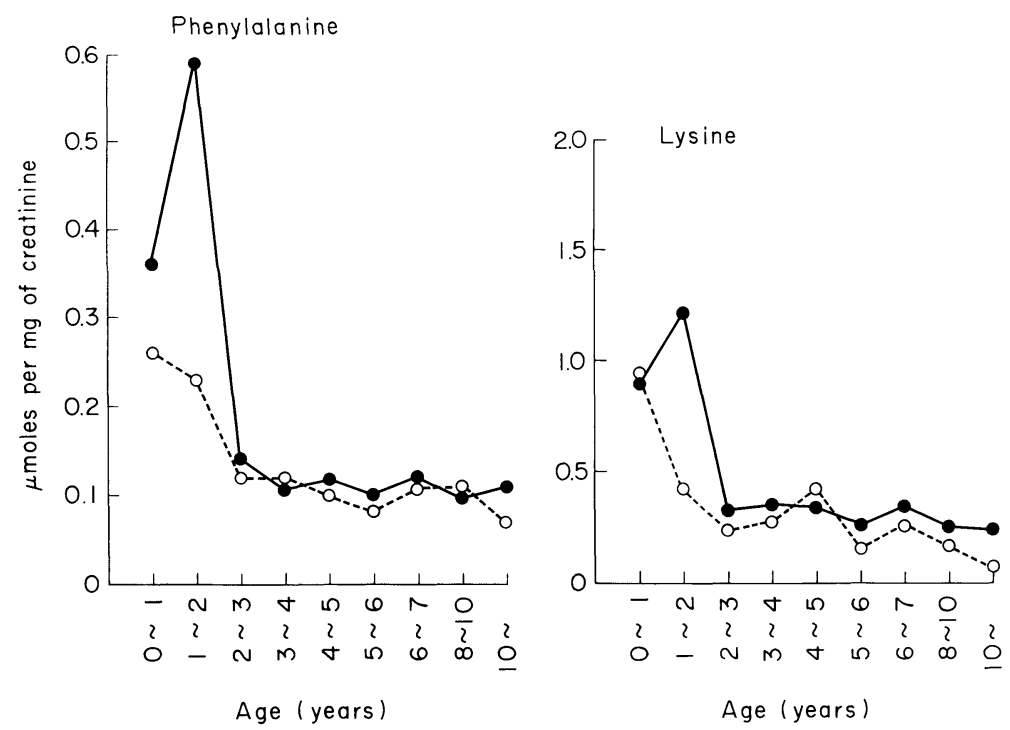

Fig. 5. Phenylalanine and lysine in urine of male infants and children (for symbols, see Fig. 1). 


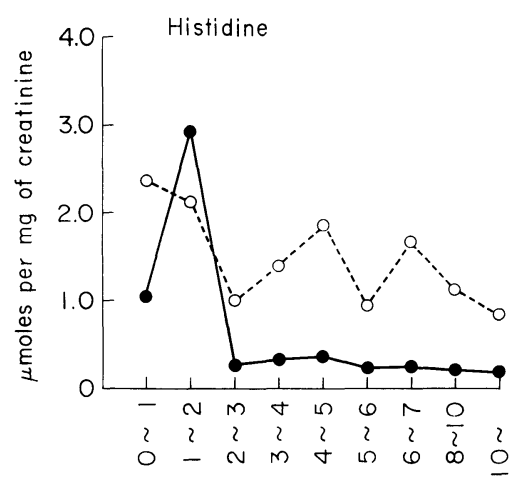

Age (years)

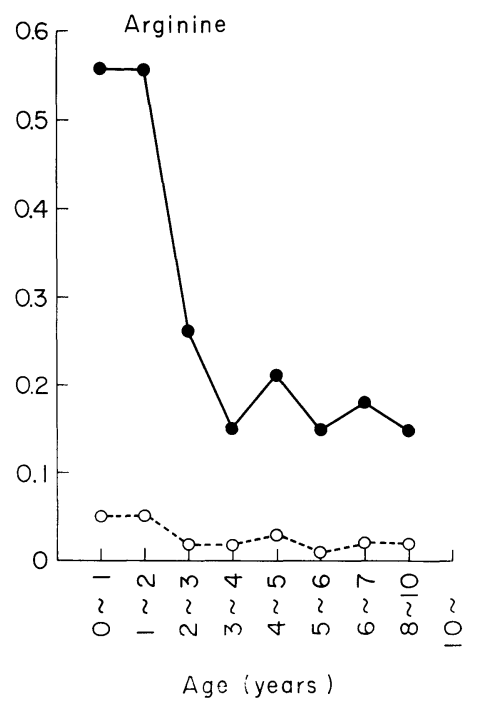

Fig. 6. Histidine and arginine in urine of male infants and children (for symbols, see Fig. 1).

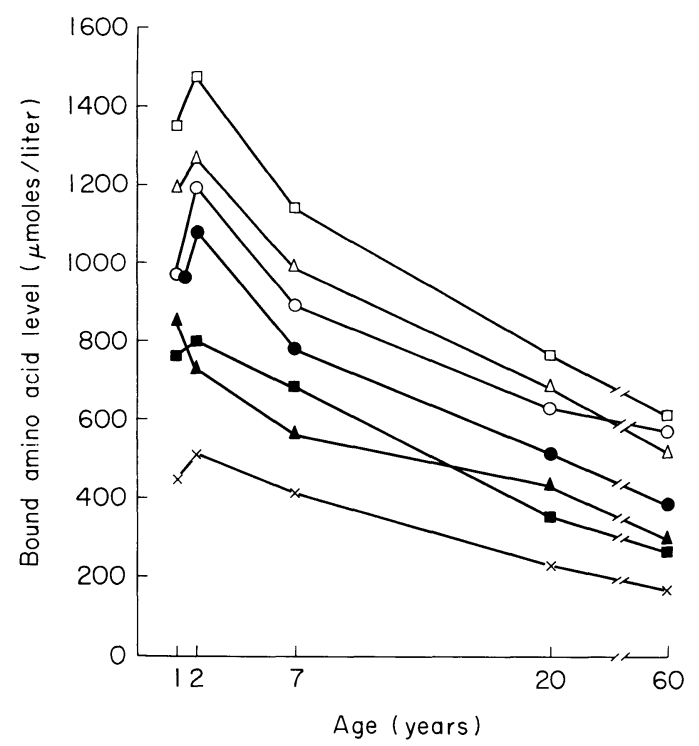

Fig. 7. Bound amino acid levels in plasma (fasting).

$\square-\square$, leucine; $\Delta-\Delta$, lysine; $\bigcirc-\circ$, glycine; $\bullet-\bullet$, valine; $\times-\times$, isoleucine; $\mathbf{\Delta}-\mathbf{\Delta}$, phenylalanine; - $-\mathbf{-}$, proline.

synthesis of messenger and ribosomal RNA (Florini and Breuer 1966; Korner 1968). An increase in plasma amino acids following several days of intramuscular human growth hormone injection (Zachmann 1969) could be due to stimulation of protein synthesis.

Thus we are of the opinion that an increase in bound amino acids in plasma, resulting in an increased bound aminoaciduria, observed in infants and young 


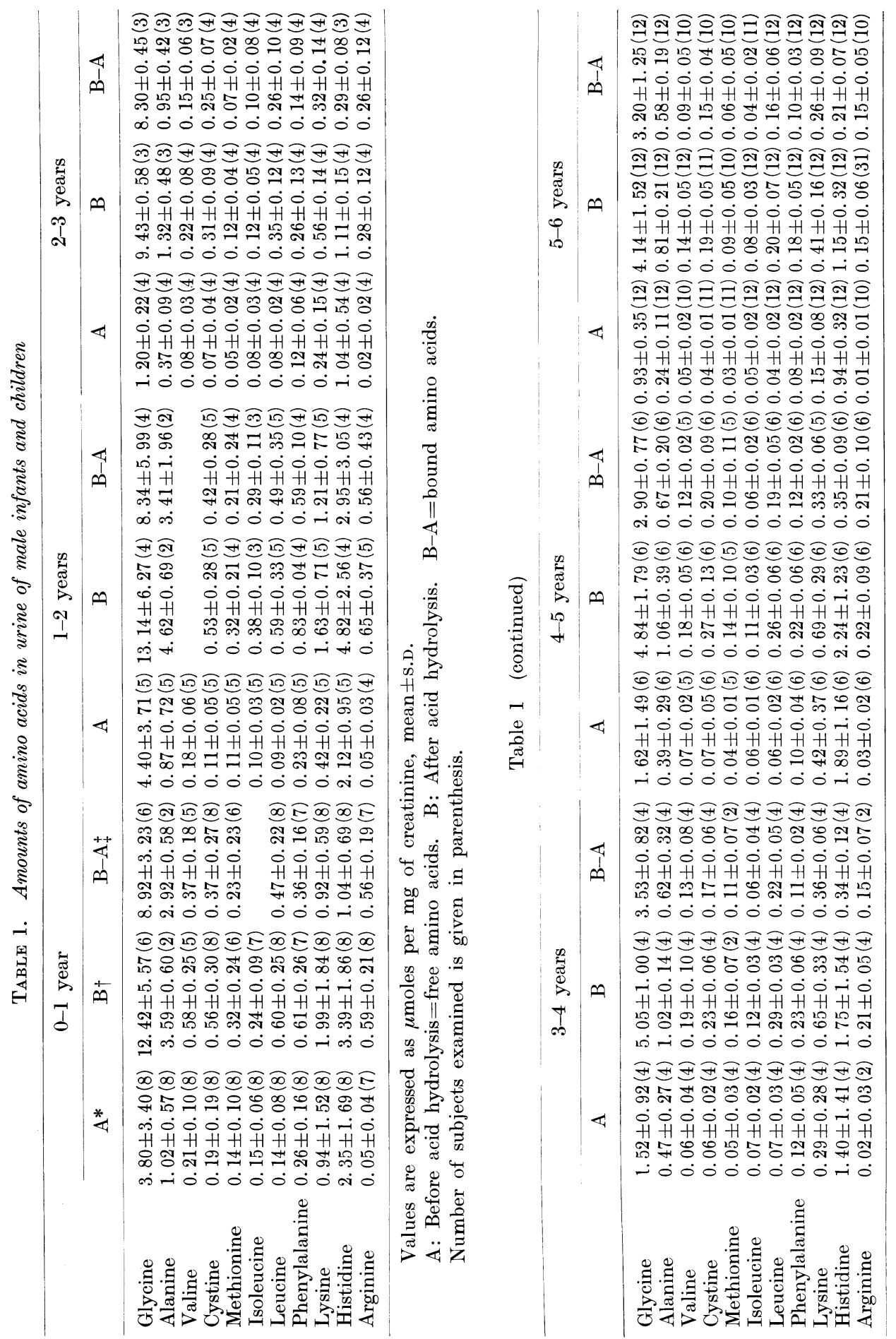



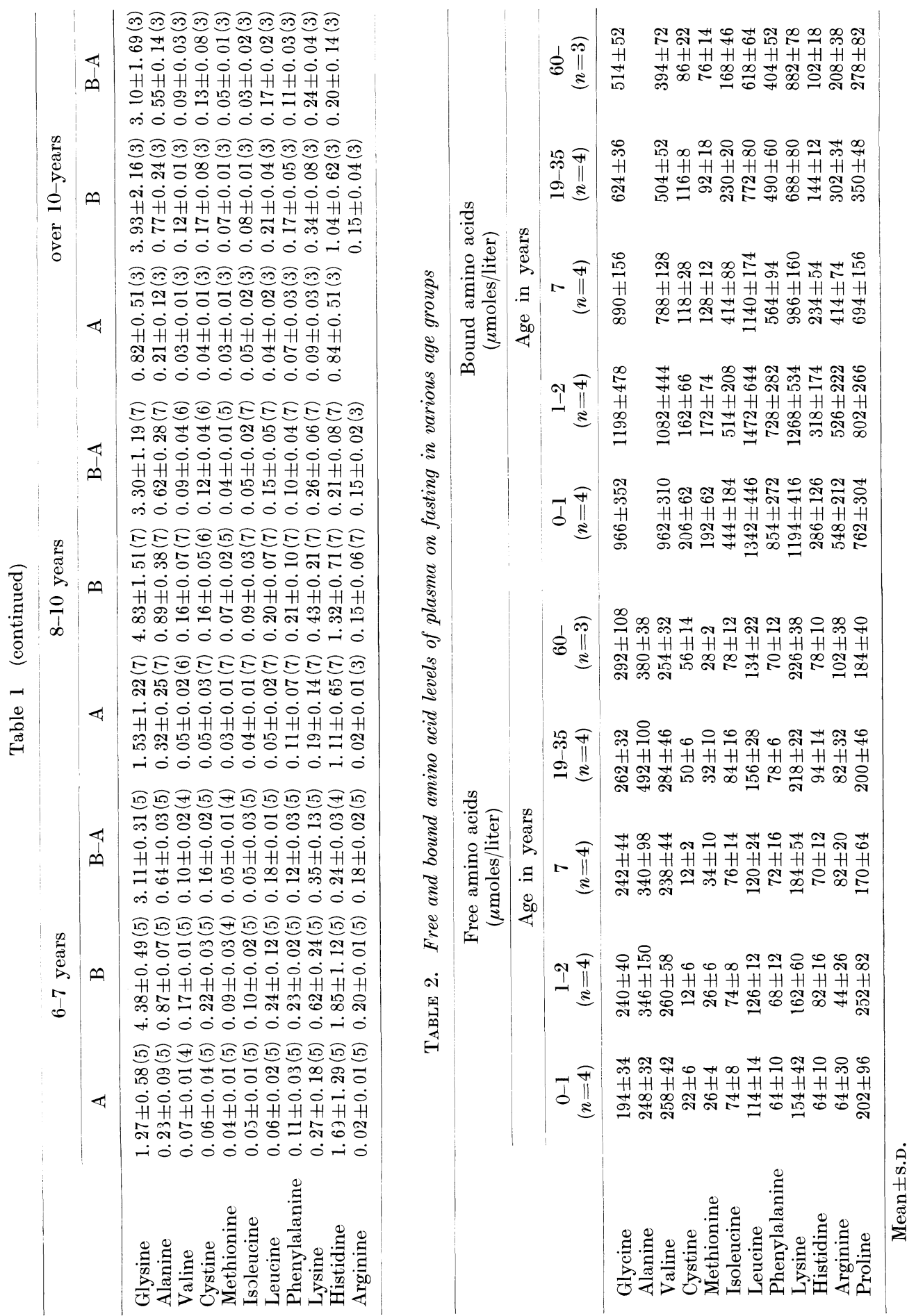
Ts. Arakawa et al.
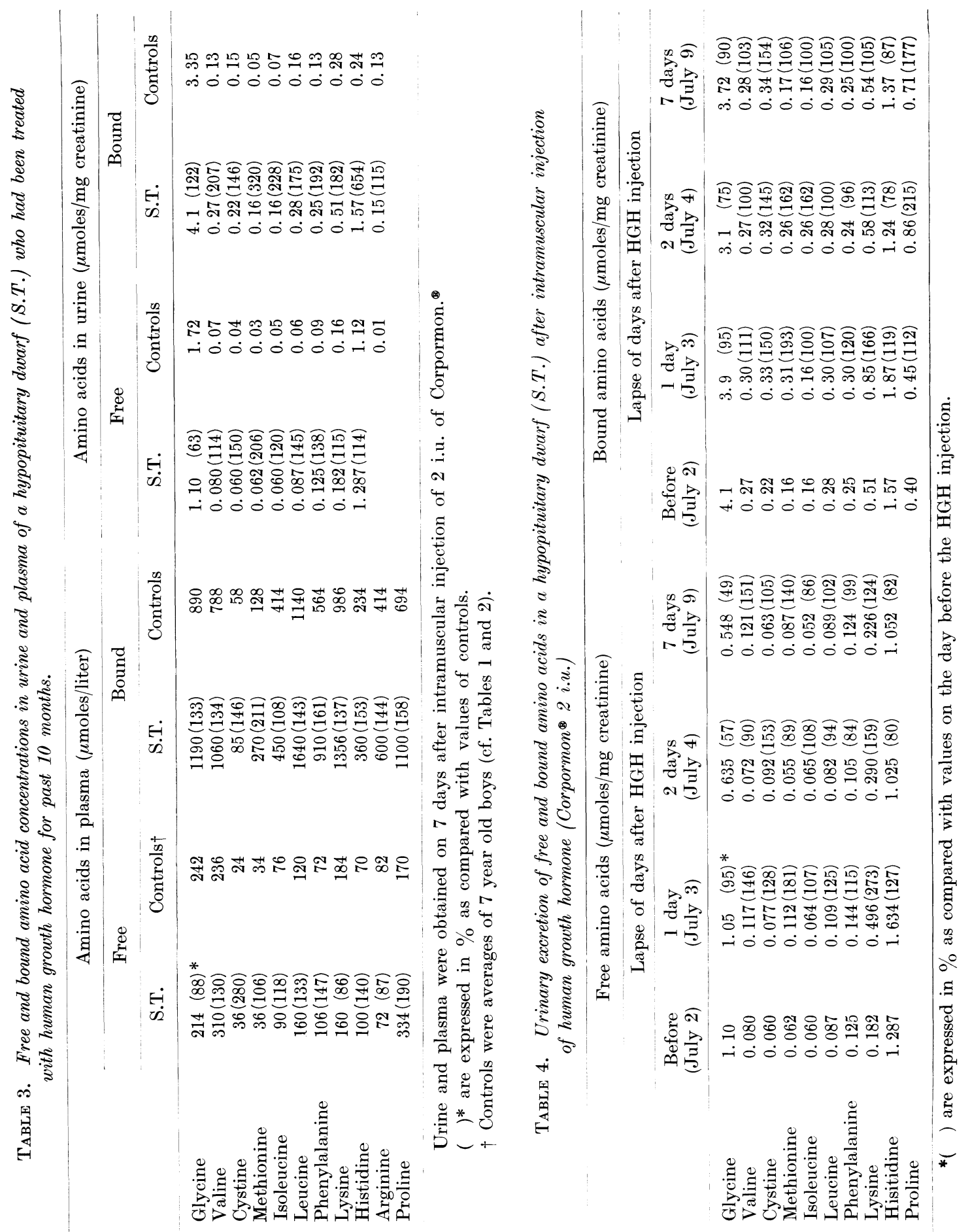


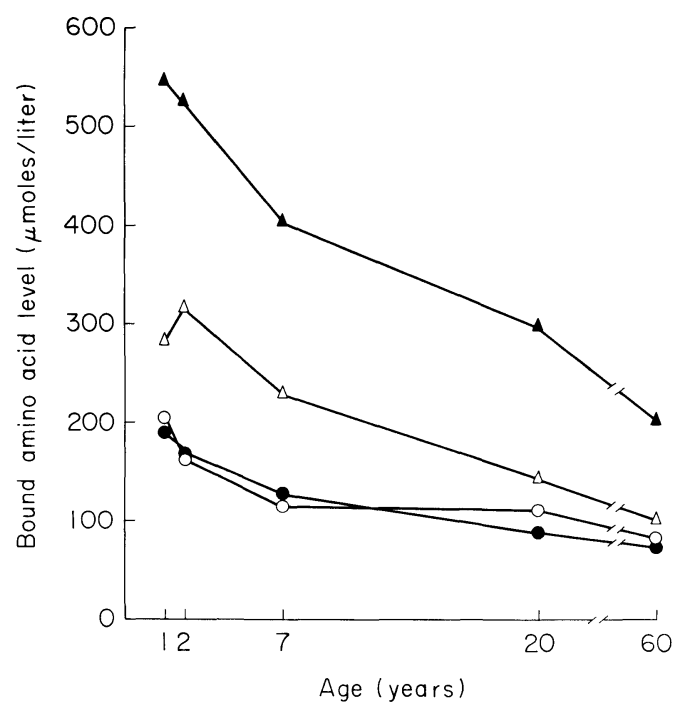

Fig. 8. Bound amino acid levels in plasma (fasting). $\Delta-\Delta$, arginine; $\Delta-\Delta$, histidine; -- $\bullet$ methionine; o-o, cystine.
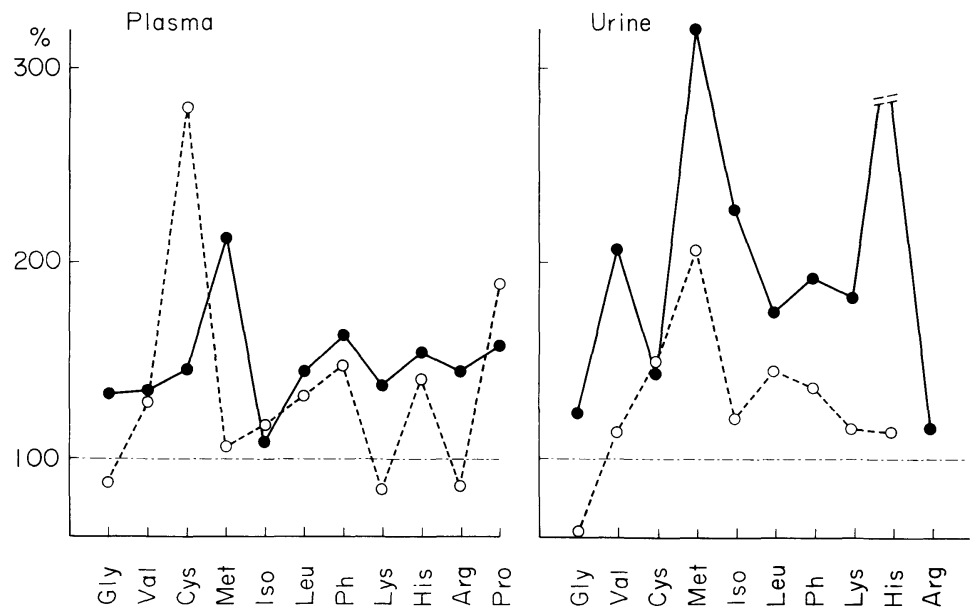

Fig. 9. Amino acid levels in plasma and urine of a hypopituitary dwarf (S.T.) who had been treated with human growth hormone, expressed as \% of those of control children. -- $\bullet$, bound amino acids; $0 \cdots$, free amino acids.

children, might be due to stimulation of protein biosynthesis by high plasma levels of human growth hormone in these age groups (Glick et al. 1965).

As regards an increased bound aminoaciduria, it was of interest to note the report of Berman and Kench (1968). They studied the urinary excretion of free and bound amino acids in four children who were suffering from kwashiorkor and found that the most marked increase in excretion of bound amino acids occurred 1-3 days after protein feeding had begun. In 1960 Potgieter et al. found that 
serum albumin began to rise after 3 days of protein feeding in kwashiorkor, and even more dramatic increase of certain globulin fractions was noted. From these findings, Berman and Kench (1968) suggested that release of protein into the circulation and increased peptiduria might be interrelated, and that the increased bound aminoaciduria was due to liberation of abortive peptide fragments arising out of protein synthesis when sequential synthesis of the polypeptide chain was halted by depletion of limiting intracellular amino acids in kwashiorkor.

From results of our present study, it might be assumed that an increased bound aminoaciduria of the overflow type observed in infants was due to liberation of bound amino acids from tissues where protein biosynthesis was stimulated by the high plasma levels of growth hormone in infancy.

\section{References}

1) Berman, M.C. \& Kench, J.E. (1968) Role of peptides in protein metabolism: Peptiduria in protein depleted children. Clin. Sci., 34, 111-123.

2) Bonsness, R.W. \& Taussky, H.H. (1945) On the colorimetric determination of creatinine by the Jaffe reaction. J. biol. Chem., 158, 581-591.

3) Florini, J.R. \& Breuer, C.B. (1966) Amino acid incorporation into protein by cellfree system from rat skeletal muscle. Biochemistry, 5, 1870-1876.

4) Korner, A. (1968) Anabolic action of growth hormone. Ann. N.Y. Acad. Sci., 148, $408-418$.

5) Glick, S.M., Roth, J., Yalow, R.S. \& Berson, S.A. (1965) The regulation of growth hormone secretion. Recent Progr. Hormone Res., 21, 241-283.

6) Potgieter, G.M., Smythe, P.M. \& Kench, J.E. (1960) Serum proteins in kwashiorkor. S. Afr. med. J., 34, 841-842.

7) Silber, R.H. \& Porter, C.C. (1949) Urinary excretion of amino acids and peptides by dogs fed protein hydrolysates or amino acids. J. Nutr., 38, 155-164.

8) Skarzynski, B. \& Sarnecka-Keller, M. (1962) Peptides in human urine. Advanc. clin. Chem., 5, 107-134.

9) Stahnke, N., Plettner, C. \& Blunck, W. (1977) Effects of growth hormone on protein metabolism. Acta paediat. scand., 66, 153-159.

10) Zachmann, M. (1969) Influence of human growth hormone on plasma and urine amino acid concentrations in hypopituitary dwarfs. Acta endocr., 62, 513-520. 